\title{
Pengaruh Persepsi Kegunaan, Kemudahan Penggunaan dan Risiko Terhadap Minat Mahasiswa Menggunakan Sistem Blockchain
}

\author{
Dewa Ayu Dita Witami ${ }^{1}$ \\ I Wayan Suartana ${ }^{2}$
}

\author{
${ }^{1,2}$ Fakultas Ekonomi dan Bisnis, Universitas Udayana (Unud), Bali, Indonesia \\ e-mail:ditawitami@gmail.com
}

\begin{abstract}
ABSTRAK
Tujuan penelitian ini adalah untuk mengetahui pengaruh persepsi kegunaan, persepsi kemudahan menggunakan dan persepsi risiko terhadap minat menggunakan sistem blockchain dalam teknologi keuangan.Populasi penelitian ini adalah mahasiswa S1 jurusan akuntansi FEB UniversitasUdayana angkatan 2015-2018. Metode Penentuan sampel pada penelitian ini menggunakan teknik sampling jenuh. Sampel dalam penelitian ini berjumlah 294 orang. Metode pengumpulan data yang digunakan adalah metode survei dengan kuesioner. Teknik analisis data yang digunakan adalah analisis regresi linear berganda. Berdasarkan hasil analisis ditemukan bahwa persepsi kegunaan dan persepsi kemudahan menggunakan berpengaruh positif terhadap minat menggunakan sistem blockchain dalam teknologi keuangan. Namun persepsi risiko berpengaruh negatif terhadap minat menggunakan sistem blockchain dalam teknologi keuangan.

Kata kunci:Persepsi kegunaan, persepsi kemudahan menggunakan, persepsi risiko dan minat menggunakan sistem blockchain.
\end{abstract}

\begin{abstract}
The purpose of this study was to determine the effect of perceived usefulness, perceived ease of use and risk perception of interest in using the blockchain system in financial technology. The population of this study was undergraduate students majoring in accounting FEB Udayana University class of 2015-2018. Methods Determination of samples in this study using saturated sampling techniques. The sample in this study amounted to 294 people. The data collection method used is the survey method with a questionnaire. The data analysis technique used is multiple linear regression analysis. Based on the results of the analysis it was found that perceived usefulness and perceived ease of use had a positive effect on the interest in using the blockchain system in financial technology. But the perception of risk has a negative effect on interest in using the blockchain system in financial technology.

Keywords: Perception of usability, perception of ease of use, perception of risk and interest in using the blockchain system.
\end{abstract}

\section{PENDAHULUAN}

Perkembangan teknologi informasi dan komunikasi yang semakin maju di berbagai belahan dunia telah membawa perubahan yang besar terhadap berbagai sektor kehidupan kita (Aritonang \& Arisman, 2017). Sektor yang paling menyentuh atau paling banyak di kaitkan dengan teknologi informasi adalah 
sektor perbankan atau yang menjurus pada perekonomian (Langelo, 2013). Revolusi industri 4.0 menitikberatkan revolusi pada fenomena disruptive innovation, yang dapat didefinisikan sebagai sebuah inovasi yang mampu menciptakan pasar baru namun mengganggu atau bahkan merusak pasar yang sudah ada. Disruptive innovation mengembangkan suatu produk atau layanan yang tidak diduga oleh pasar yang umumnya dilakukan dengan menciptakan jenis konsumen berbeda pada pasar yang baru tersebut.

Era industri 4.0 adalah istilah yang digunakan untuk merujuk pada era dimana terjadi perpaduan teknologi yang mengakibatkan dimensi fisik, biologis, dan digital membentuk suatu perpaduan yang sulit untuk dibedakan (Schwab, 2016). Misalnya, dua orang dapat saling berbagi informasi secara langsung dengan bantuan digital tanpa harus berada pada tempat yang sama atau pada waktu yang bersamaan baik secara fisik maupun biologis (Hasanah, 2018). Perkembangan revolusi industri 4.0 tidak dapat terlepas dari perkembangan internet. Internet of things (IoT) secara sederhana didefinisikan sebagai sebuah konsep yang pada dasarnya menghubungkan perangkat elektronik dengan internet atau dengan sesama perangkat elektronik lainnya melalui jaringan kompleks dengan keamanan yang tinggi.

Era revolusi dunia keempat merupakan konsep yang pertama kali di perkenalkan oleh Profesor Klaus Schwab. Beliau merupakan ekonom terkenal asal Jerman yang segaligus adalah penggagas World Economic Forum (WEF) yang melalui bukunya yaitu "The Fourth Industrial Revolution”, yang menjelaskan bahwa revolusi industry 4.0 telah mengubah hidup dan kerja manusia secara 
fundamental (Schwab, 2016). Bapak Joko Widodo, mengatakan bahwa revolusi 4.0 telah mendorong inovasi-inovasi teknologi yang memberikan dampak disrupsi atau perubahan fundamental terhadap kehidupan masyarakat (Beritautama.net, 2018).

Era revolusi industri 4.0 memiliki masa depan yaitu suatu sistem yang bernama Blockchain. Blockchain pertama kali diperkenalkan oleh Satoshi Nakamoto pada tahun 2008. Blockchain merupakan suatu teknologi yang tidak menggunakan pihak ketiga dalam proses pertukaran data yang dalam hal ini terjadi pada suatu proses transaksi. Blockchain juga dapat dikatakan sebagai suatu sistem pencatatan atau database untuk suatu transaksi di jaringan atau disebut dengan distributed ledger. Database transaksi terdesentralisasi mampu merekam peristiwa, catatan dan aktivitas record dalam sistem yang aman, transparan dan efisien. Blockchain dapat membawa dampak yang positif untuk Indonesia berkat transparansi dan efisiensinya. Blockchain sama dengan teknologi internet dimana blockchain dapat mendisrupsi ke semua sektor.

Dengan adanya era industri 4.0 yang menjadikan sistem Blockchain sebagai masa depan, dapat di rasakan saat ini yang berbeda dengan tahun sebelumnya. Perkembangan dari revolusi 4.0 yang menghadirkan sistem Blockchain telah melahirkan sistem pembayaran yang bukan hanya menggunakan sistem tunai saja (kertas atau logam) tetapi juga menggunakan sistem pembayaran non tunai (bukan kertas atau logam). Saat ini, sistem pembayaran non tunai berkembang pesat seiring dengan kemajuan teknologi. Perkembangan teknologi memberikan kontribusi signifikan terhadap industrialisasi yang memicu pertumbuhan ekonomi. 
Kombinasi keduanya, kemajuan teknologi dan kemajuan ekonomi, menghasilkan inovasi baru dalam sistem informasi akuntansi, khususnya pada sistem pembayaran. Salah satu inovasi yang dihasilkan adalah adanya perubahan metode pembayaran yang digunakan (Hapsari, 2015). Sejalan dengan hal tersebut Gubernur Bank Indonesia, Agus D.W. Marto Wardjojo, secara resmi mencanangkan Gerakan Nasional Non Tunai (GNNT) pada pertengahan Agustus 2014. Menurut beliau, GNNT ditujukan untuk meningkatkan kesadaran masyarakat terhadap penggunaan instrumen keuangan non tunai, yang jika diterapkan secara konsisten dalam jangka panjang akan terbentuk suatu komunitas/masyarakat pengguna instrumen non tunai (Less Cash Society). (Departemen Komunikasi Bank Indonesia, 2014).

Tabel 1.

Jumlah Uang Elektronik Beredar di Indonesia Tahun 2013-2017

\begin{tabular}{cc}
\hline Tahun & $\begin{array}{c}\text { Nominal } \\
\text { (Dalam Juta Unit) }\end{array}$ \\
\hline 2013 & 36.225 .375 \\
2014 & 35.738 .233 \\
2015 & 34.314 .795 \\
2016 & 51.204 .580 \\
2017 & 90.003 .848 \\
\hline
\end{tabular}

Sumber: Bank Indonesia, 2018

Berdasarkan data tabel 1 dapat disimpulkan bahwa pada tahun 2013 sampai dengan tahun 2017, volume jumlah uang elektronik yang beredar meningkat 7 kali lipat. Kenaikan yang cukup dahsyat juga terlihat pada tahun 2016 menuju tahun 2017. Dimana kenaikan yang terjadi sebesar 38.799.268 juta unit (Statistik Sistem Pembayaran, 2018). Kenaikan tersebut sebagian besar disebabkan oleh keluarnya Peraturan Menteri Pekerjaan Umum dan Perumahan Rakyat Republik Indonesia Nomor 16/PRT/M/2017 tentang Transaksi Tol Non Tunai di Jalan Tol yang 
menyatakan bahwa penerapan transaksi pembayaran tol non tunai sepenuhnya di seluruh jalan tol per 31 Oktober 2017. Merujuk pada Peraturan Bank Indonesia Nomor 18/40/PBI/2016 tentang Pemrosesan Transaksi Pembayaran, dompet elektronik atau electronic wallet adalah sebuah layanan elektronik untuk menyimpan data instrumen pembayaran antara lain alat pembayaran dengan menggunakan kartu dan/atau uang elektronik, yang dapat juga menampung dana untuk melakukan pembayaran (Bank Indonesia, 2016)

Dilihat dari sistem blockchain yang sudah berjalan pada beberapa alat pembayaran elektronik di Indonesia, maka dalam penelitian ini peneliti ingin meneliti mengenai minat Mahasiswa akuntansi Fakultas Ekonomi dan Bisnis Universitas Udayana dalam menggunakan sistem blockchain. Namun pada dasarnya peneliti harus mengetahui bagaimana minat seseorang untuk menggunakan suatu sistem tersebut. Untuk mengetahui bagaimana minat mahasiwa akuntansi S1 peneliti mengukurnya dengan tiga persepsi yaitu persepsi kegunaan, persepsi kemudahan penggunaan dan risiko menggunakan.

Berdasarkan latar belakang yang telah dipaparkan diatas, peneliti tertarik untuk menegetahui faktor-faktor yang dapat mempengaruhi minat mahasiswa S1 program studi akuntansi Fakultas Ekonomi dan Bisnis Universitas Udayana dalam menggunakan sistem Blockchain dalam bertransaksi menggunakan teknologi keuangan. Peneliti berpendapat bahwa menggunakan sistem Blockchain dalam teknologi keuangan yang ada saat ini dapat menghemat waktu dan praktis dalam bertansaksi dan melakukan kegiatan. Berdasarkan penjelasan diatas, maka peneliti melakukan penelitian terkait pengaruh persepsi kegunaan, persepsi kemanfaatan 
Dewa Ayu Dita Witami dan I Wayan Suartana. Pengaruh ...

dan persepsi risiko terhadap minat menggunakan sistem blockchain dalam teknologi keuangandengan penelitian yang berjudul "Pengaruh Persepsi Kegunaan, Kemudahaan Penggunaan dan Resiko Pada Minat Mahasiswa Menggunakan Sistem Blockchain”.

Berdasarkan pokok permasalahan yang telah diuraikan, maka tujuan penelitian ini adalah untuk menguji secara empiris pengaruh persepsi kegunaan Blockchain pada minat mahasiswa akuntansi Universitas Udayana dalam menggunakan sistem Blockchain pada teknologi keuangan.Untuk menguji secara empiris pengaruh persepsi kemudahan penggunaan Blockchain pada minat mahasiswa akuntansi Universitas Udayana dalam menggunakan sistem Blockchain pada teknologi keuangan.Untuk menguji secara empiris pengaruh persepsi risiko penggunaan Blockchain pada mahasiswa akuntansi Universitas Udayana dalam penggunaan Blockchain pada teknologi keuangan.

Theory of Reasoned Action atau sering di sebut dengan teori tindakan beralasanmerupakan teori yang pertama kali di cetuskan oleh (Fishbein \& Ajzen, 1975). Konsep yang sangat penting dalam teori ini adalah fokus perhatian (salience) yaitu mempertimbangkan sesuatu yang dianggap penting. Kehendak (intention) ditentukan oleh sikap dan norma subyektif (Jogiyanto, 2007). Teori ini disusun menggunakan asumsi bahwa manusia berperilaku dengan cara yang sadar dan mempertimbangkan segala informasi yang tersedia. Ajzen dan Fishbein dalam Sayuti (2012) berasumsi bahwa pengadopsian suatu teknologi pada umumnya ditentukan oleh proses kognitif dan bertujuan untuk memuaskan pemakainya atau 
memaksimalkan kegunaan teknologi itu sendiri. Kunci utama dari penerimaan teknologi informasi menurut TRA adalah evaluasi kegunaan teknologi tersebut.

Teori tindakan beralasan atau Theory of Reasoned Action (TRA) atau teori aksi beralasan mengatakan bahwa sikap mempengaruhi perilaku melalui suatu proses pengambilan keputusan yang teliti dan beralasan, dan dampaknya terbatas hanya pada tiga hal. Pertama, perilaku tidak banyak ditentukan oleh sikap umum tetapi oleh sikap yang spesifik terhadap sesuatu. Kedua, perilaku tidak hanya dipengaruhi oleh sikap tetapi juga oleh norma subyektif (subjective norms) yaitu keyakinan kita mengenai apa yang orang lain inginkan agar kita lakukan. Ketiga, sikap terhadap suatu perilaku bersama-sama norma subyektif membentuk suatu intensi atau niat untuk berperilaku tertentu.

Theory of Reasoned Action ini juga memberikan beberapa keuntungan karena teori ini memberikan pegangan untuk menganalisis komponen perilaku dalam item yang operasional. Fokus sasaran adalah prediksi dan pengertian perilaku yang dapat diamati secara langsung dan berada dalam kendali seseorang, artinya perilaku sasaran harus diseleksi dan diidentifikasi secara jelas. Tuntutan ini memerlukan pertimbangan mengenai perbedaan tindakan (action), sasaran (target), konteks dan perbedaan waktu serta komponen model sendiri termasuk intensi, sikap, norma subjektif dan keyakinan.

Theory of Planned Behaviour (TPB) atau teori yang berhubungan dengan keyakinan (belief) dan tingkah laku (behavior). Teori ini merupakan konsep yang diusulkan oleh (Azjen, 1991). Terdapat perbedaan antara model TPB dengan TRA yaitu dengan adanya tambahan satu elemen yang disebut perceived 
behavioral control (PBC). Kemampuan mengontrol juga dapat didefinisikan sebagai persepsi atau kontruk-konstruk internal dan internal perilaku (Taylor \& Todd, 1995). TPB menjelaskan mengenai perilaku spesifik dalam diri individu. Teori ini memprediksi dan menjelaskan perilaku manusia dalam konteks tertentu.

Menurut TPB sikap terhadap lingkungan dipengaruhi oleh pandangan seseorang mengenai hasil dari tindakanya, dimana pandangan tersebut dipengaruhi oleh karakter personal dari masing - masing individu seperti pengaruh lingkungan keluarga, keyakinan bahwa tindakan perilaku yang dilakukan akan membawa kepada hasil yang diinginkan(Jayawarna, Rouse, \& Kitching, 2013).

Teori Technology Acceptance Model (TAM) dikembangkan oleh (Davis, 1989). Teori ini disusun berdasarkan oleh dua teori dasar mengenai penerimaan teknologi yang telah dikembangkan sebelumnya yaitu Theory of Reasoned Action (TRA) dan Theory of Planned Behavior (TPB). Technology Acceptance Model (TAM)merupakan model penelitian yang paling populer untuk mengasumsikan kegunaan dan penerimaan individu atas perkembangan teknologi dan sistem informasi. Dalam teori ini terdapat dua variabel utama yang memengaruhi penerimaan individu atas perkembangan teknologi dan sistem informasi yaitu, Perceived Usefulness (Persepsi Kegunaan) dan Perceived Ease of Use (Persepsi Kemudahan Penggunaan).

Menurut Lai (2017) menyatakan bahwa Perceived Ease of Use dan Perceived Usefulness memengaruhi Attitude Toward Using, yang mana dikonsepkan sebagai sikap terhadap penggunaan sistem yang berbentuk 
penerimaan atau penolakan sebagai dampak penggunaan teknologi dalam pekerjaan, terhadap penggunaan teknologi. Peningkatan Perceived Ease of Use akan meningkatkan Perceived Usefulness. Hal tersebut disebabkan karena sebuah sistem yang mudah digunakan tidak akan membutuhkan waktu lama untuk dipelajari, sehingga efektivitas dalam bekerja dapat dimaksimalkan (Irmadhani \& Nugroho, 2012). Hal tersebut menunjukkan bahwa persepsi kegunaan dan persepsi kemudahan penggunaan berpengaruh terhadap Behavioral Intention to Use atau kecenderungan untuk tetap menggunakan suatu teknologi atau sistem tersebut. Actual System Usage adalah kondisi nyata pengguna sistem yang dikonsepkan dalam pengukuran terhadap frekuensi dan durasi waktu penggunaan teknologi (Wibowo, 2008).

Venkatesh dan Davis (2002) melakukan pengembangan pada model TAM, dan menghasilkan TAM-2 dengan mengikutsertakan dua faktor luar, yaitu pengaruh sosial (social influence processes) sebagai variabel pertama dengan beberapa variabel yaitu, norma subjektif (subjective norm), voluntariness dan image. Variabel kedua adalah, instrumental kognitif (cognitive instrumental processes) dengan beberapa variabel seperti, job relevance, output quality, result demonstrability dan experience (Sayuti, 2012). 


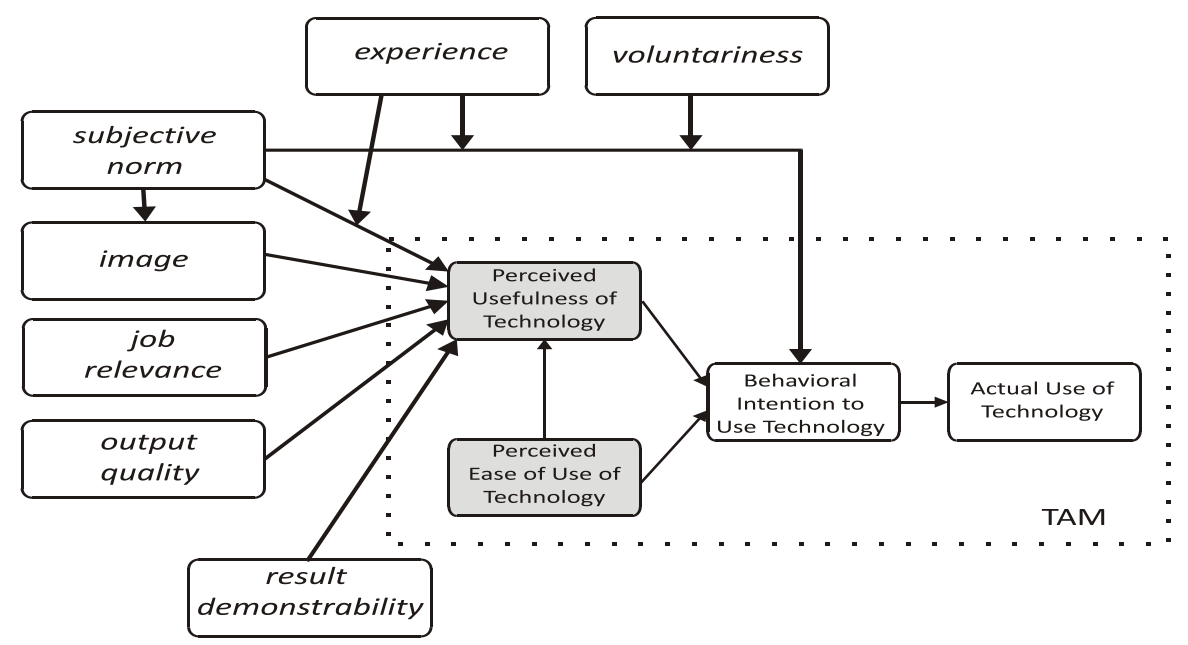

Gambar 1. Technology Acceptance Model- 2 (TAM-2)

Sumber: Davis, 2000

Dalam penelitian kali ini, penulis akan menggunakan teori Final Version of

Technology Acceptance Model. Penulis menganggap teori tersebut paling relevan dengan konsep penelitian yang telah penulis bangun. Karena dalam penelitian kali ini, penulis ingin mengetahui pengaruh langsung Persepsi Kemanfaatan, Persepsi Kemudahan Penggunaan dan Persepsi Resiko terhadap minat atau sikap para pengguna teknologi dalam memanfaatkan layanan Mobile Banking. Sementara pada pengembangan TAM-2 meneliti banyak faktor eksternal yang mempengaruhi ketiga persepsi tersebut. Penulis merasa pada penelitian kali ini tidak diperlukan meneliti faktor eksternal yang memengaruhi.

Persepsi kegunaan (Perceived Use Fullness) didefinisikan sebagai sejauh mana seseorang percaya bahwa menggunakan suatu teknologi akan meningkatkan prestasi kerja dirinya (Davis, 1989). Ramatsyah, (2011) mengartikan persepsi kemanfaatan sebagai propabilitas subyektif dari pengguna potensial yang menggunakan suatu aplikasi tertentu untu mempermudah kinerjanya. Menurut Wibowo, (2008) mengatakan bahwa persepsi kegunaan didefinisikan sebagai 
suatu ukuran yang mana penggunaan suatu teknologi dipercaya akan mendatangkan manfaat bagi orang yang menggunakannya. Persepsi Kemudahan Penggunaan merupakan derajat di mana individu percaya bahwa teknologi yang digunakan mudah untuk dipahami dan mudah digunakan. Kemudahan penggunaan dapat mengurangi usaha seseorang, baik waktu maupun tenaga, untuk mempelajari dan beradaptasi dengan sistem atau teknologi (Irmadhani \& Nugroho, 2012).

Risiko adalah suatu keadaan uncertainty yang dipertimbangkan orang untuk memutuskan atau tidak melakukan transaksi secara online. Kecenderungan risiko adalah tendensi seseorang dalam pengambilan keputusan apakah seseorang tersebut akan mengambil atau menghindari risiko yang ada (Cho, J. \& Lee, 2006). Persepsi risiko merupakan suatu persepsi tentang ketidakpastian dan konsekuensikonsekuensi tidak diinginkan dari menggunakan suatu produk atau suatu layanan (Pratiwi, 2015). Persepsi terhadap risiko dapat memainkan peran yang sangat penting dalam perilaku manusia khususnya terkait pada pengambilan keputusan dalam keadaaan tidak pasti (Lestari, 2013). Terdapat dua pengukuran risiko dari sisi behavioral adalah persepsi risiko (risk perception) dan kecenderungan terhadap risiko (risk propensity).

Intensi merupakan sebuah indikasi seberapa banyak usaha yang dilakukan untuk menunjukkan suatu perilaku (Wardhana, 2016). Dengan kata lain, minat juga dapat didefinisikan sebagai kecenderungan ketertarikan pada sesuatu yang relatif tetap untuk lebih memperhatikan dan mengingat secara terus menerus yang diikuti rasa senang untuk memeroleh sebuah kepuasan dalam mencapai. Minat 
merupakan keinginan yang kuat yang timbul dari diri seseorang karena adanya ketertarikan, kesukaan untuk mencapai sutau tujuan tertentu (Kusumastuti \& Waluyo, 2019).

Istilah Blockchain pertama kali dikenalkan oleh Satoshi nakamoto pada tahun 2008 lalu. Blockchain adalah sebuah sistem penyimpanan data digital yang terdiri dari banyak server (multiserver). Pada teknologi blockchain, data yang dibuat oleh sutu server dapat direplikasi dan diverifikasi oleh server yang lain. Dengan adanya blockchain, sebuah transaksi tidak perlu lagi beruntung pada satu server karena transaksi yang dilakukan akan tereplikasi ke seluru jaringan yang ada. Sistem Blockchain tidak menggunakan pihak ketiga sebagai pusatnya, namun menggunakan banyak pihak atau computer yang tersebar di jaringan itu sendiri. Blockchain dapat membuat orang asing yang tidak bertanggung jawab menjadi kesulitan melakukan pembobolan pada sistem dan mempunyai gangguan yang kemungkinan kecil akan terjadi. Blockchain pertama kali dikenalkan oleh Satoshi Nakamoto, pria berkebangsaan Jepang-Amerika Serikat pada tahun 2008 lalu. (Satoshi \& Nakamoto, 2008).

Hasil penelitian Cahyo (2014) menunjukan persepsi kebermanfaatan berpengaruh positif dan signifikan terhadap pengguna Online Banking. Selain itu, penelitian yang dilakukan oleh Sari (2013) menunjukan hasil yang sama dimana persepsi kebermanfaatan positif dan siginifikan terhadap pengguna E-Banking. Selain itu, persepsi kegunaan menunjukkan apakah pengguna yakin untuk menggunakan sistem yang ada dapat membantu pekerjaan mereka. Penelitian yang dilakukan oleh Farizi \& Syaefullah (2013), Andrie (2012) dan Prasada 
Bangkara \& Mimba (2016) menunjukkan bahwa persepsi kegunaan (perceived usefulness) berpengaruh positif terhadap minat pemanfaatan teknologi. Penelitian yang dilakukan oleh Ozturk (2016) mengenai penerimaan konsumen dalam penggunaan sistem pembayaran non tunai pada industri perhotelan juga menunjukkan bahwa persepsi kegunaan berpengaruh positif dan berdampak langsung dengan minat penggunaan pembayaran non tunai.Oleh karena itu dalam penelitian ini dirumuskan hipotesis sebagai berikut:

$\mathrm{H}_{1}$ : Persepsi kegunaan berpengaruh positif pada minat menggunaan sistem blockchain dalam teknologi keuangan.

Hasil penelitian sebelumnya mengenai pengaruh persepsi kemudahan penggunaan terhadap minat penggunaan menunjukkan hasil yang beragam. Penelitian Farizi \& Syaefullah (2014) menunjukkan bahwa persepsi kemudahan penggunaan tidak berpengaruh terhadap minat menggunakan internet banking. Sementara penelitian Prasada Bangkara \& Mimba (2016), Irmadhani \& Nugroho (2012), menunjukkan bahwa persepsi kemudahan penggunaan berpengaruh terhadap minat pemanfaatan teknologi. Dewantara (2015) dalam penelitiannya menunjukkan bahwa persepsi kemudahan penggunaan berpengaruh positif terhadap minat penggunaan sistem dan teknologi. Semakin sistem atau teknologi tersebut mudah digunakan (effortless) dan user friendly, maka semakin tinggi pula minat pengguna untuk menggunakan sistem tersebut. Hal tersebut karena, pengguna akan cenderung memilih sesuatu yang praktis dan mudah dipahami agar pekerjaan mereka selesai secara efektif dan efisien. Oleh karena itu, dalam penelitian ini dirumuskan hipotesis: 
$\mathrm{H}_{2}$ : Persepsi Kemudahan Penggunaan berpengaruh positif pada minat penggunaan sistem blockchain dalam teknologi keuangan.

Penelitian mengenai pengaruh risiko terhadap minat penggunaan E-banking pernah dilakukan oleh (Dwimastia Harlan, 2014), dimana hasil penelitian tersebut menunjukkan resiko persepsian memiliki pengaruh negatif signifikan terhadap minat menggunakan E-banking. Selain itu, Sebayang (2017) menyatakan risiko berpengaruh signifikan terhadap penggunaan layanan mobile banking. Dalam penelitian kali ini, persepsi risiko penggunaan didefinisikan sebagai sejauh mana pengguna berkeyakinan bahwa dengan menggunakan sistem blockchain dalam sistem pembayaran tidak akan menimbulan masalah dalam penggunaan. Oleh karena itu, dalam penelitian ini dirumuskan hipotesis:

$\mathrm{H}_{3}$ : Persepsi Risiko berpengaruh negatif pada minat penggunaan sistem Blockchain dalam teknologi keuangan.

\section{METODE PENELITIAN}

Desain penelitian memberikan prosedur untuk mendapatkan informasi yang diperlukan untuk menyusun atau menyelesaikan masalah dalam penelitian. Desain penelitian merupakan dasar dalam melakukan penelitian. Oleh karena itu, desain penelitian yang baik merupakan hal yang penting dalam melakukan penelitian yang efektif dan efisien. Jenis penelitian ini termasuk penelitian asosiatif. Penelitian asosiatif merupakan penelitian yang bertujuan untuk mengetahui hubungan anatara dua variabel atau lebih. Adapun desain penelitian di gambarkan pada Gambar 2. 


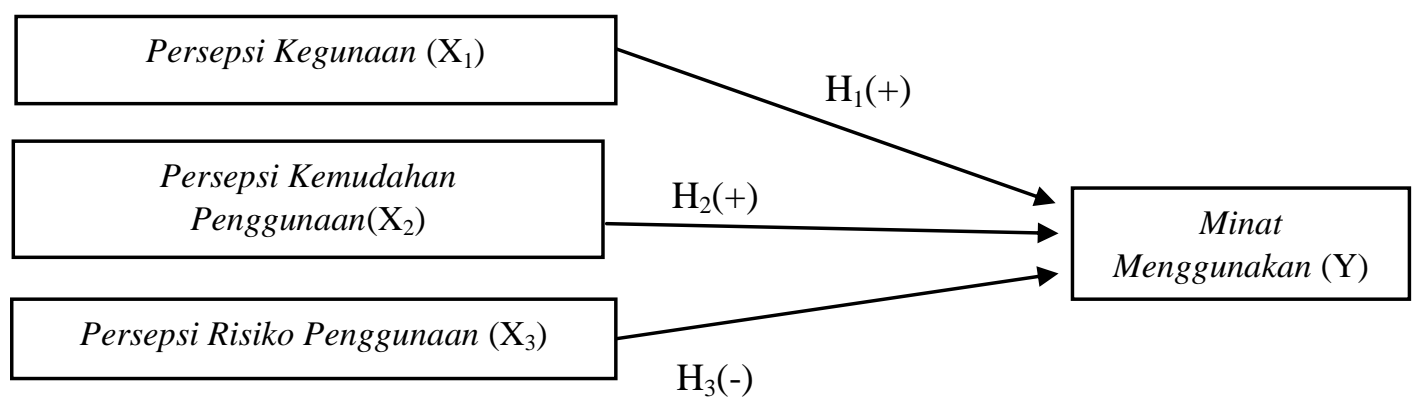

Sumber: Data diolah, 2019

\section{Gambar 2. Desain Penelitian}

Penelitian ini dilakukan pada mahasiswa jurusan akuntansi program regular pagi dan regular siang mulai dari angkatan 2015 sampai dengan angkatan 2018, Fakultas Ekonomi dan Bisnis, Universitas Udayana yang beralamat di Jalan P.B. Sudirman, Denpasar. Alasan yang mendasari dipilihnya lokasi ini dikarenakan mahasiswa sebagai generasi muda yang dianggap sebagai generasi yang paling terbuka dalam menerima hal baru.

Objek penelitian ini adalah minat penggunaan mahasiswa-mahasiswi S1 program studi akuntansi Fakultas Ekonomi dan Bisnis Universitas Udayana dalam menggunakan system blockchain dalam teknologi keuangan pada saat bertransaksi. Hal tersebut dikarenakan, mahasiswa sebagai generasi muda dianggap sebagai generasi yang paling terbuka dalam menerima sistem atau teknologi baru, yang dalam penelitian ini adalah penggunaan system blockchain dalam teknologi keuangan pada saat transaksi keuangan. Penelitian ini hanya difokuskan pada mahasiswa Fakultas Ekonomi dan Bisnis Universitas Udayana karena untuk mengetahui bagaimana persepsi mahasiswa mengenai penerimaan system blockchain dalam transaksi keuangan untuk kemudian dapat ditanggapai 
dan difasilitasi oleh pihak kampus sebagai upaya untuk mendukung Gerakan Nasional Non Tunai yang dicanangkan pemerintah.

Penelitian ini hanya dibatasi dalam lingkup mahasiswa program studi S1 Akuntansi saja karena mahasiswa akuntansi perlu menyadari bahwa perkembangan teknologi yang marak belakangan ini sangat berpengaruh pada perkembangan akuntansi. Hal ini dapat meningkatkan ketepatan waktu dalam pelaporan keuangan, mengingat dengan penggunaan system blockchain suatu proses informasi keuangan dapat disampaikan secara real time. Variabel bebas dalam penelitian ini adalah persepsi kegunaan $\left(\mathrm{X}_{1}\right)$, persepsi kemudahan penggunaan $\left(\mathrm{X}_{2}\right)$, persepsi risiko $\left(\mathrm{X}_{3}\right)$. Variabel terikat dalam penelitian ini adalah minat menggunakan sistem blockchain dalam teknologi keuangan (Y).

Populasi penelitian adalah mahasiswa aktif angkatan 2015, 2016, 2017 dan 2018 S1 program studi Akuntansi Fakultas Ekonomi dan Bisnis Universitas Udayana baik yang berkuliah di Denpasar maupun yang berkuliah di Kampus Bukit Jimbaran berjumlah 1.115 orang. Metode pengumpulan sampel yang digunakan dalam penelitian ini adalah metode simple random sampling, yang mana cara pengambilan sampel dengan memberikan kesempatan yang sama kepada setiap unsur populasi untuk terpilih menjadi sampel. Untuk mendapatkan sampel yang dapat menggambarkan populasi, maka sampel ditentukan dengan menggunakan rumus Slovin. Formula yang digunakan yaitu:

$$
\begin{aligned}
& n=\frac{N}{N(e)^{2}+1} \ldots \ldots \ldots \\
& n=\frac{1.115}{1.115(0,05)^{2}+1} \\
& n=294,2 \approx 294
\end{aligned}
$$


Keterangan:

$\mathrm{n}=$ Jumlah Sampel

$\mathrm{N}=$ Ukuran Populasi

$\Sigma=$ Batas error yang ditolerir, dalam penelitian ini sebesar 5\% atau 0,05.

Penelitian kali ini peneliti menyebarkan kuesioner secara online kepada mahasiswa-mahasiswi Program Studi Akuntansi Fakultas Ekonomi dan Bisnis Universitas Udayana dengan menggunakan aplikasi Google Forms. Alasan peneliti menggunakan aplikasi google forms adalah kuesioner bisa diisi kapan saja dan di mana saja oleh objek penelitian melalui link atau tautan yang dikirimkan peneliti.

Kuesioner penelitian ini diukur dengan menggunakan Skala likert. Skala jawaban yang digunakan dalam penelitian ini adalah skala empat poin. Hal tersebut penulis lakukan untuk menghindari kecenderungan responden menjawab ragu-ragu atau netral pada saat mengisi kuesioner, sehingga mengurangi bias. Data kualitatif dalam penelitian ini adalah instrument pernyataan dalam kuesioner dan pernyataan responden dalam pengisian kuesioner.Data kuantitatif dalam penelitian ini adalah jawaban kuesioner yang disebarkan yang kemudian diukur dengan skala likert.

Sumber data primer dalam penelitian ini adalah data yang diperoleh langsung dari responden kuesioner mahasiswa jurusan akuntansi regular pagi dan regular siang Fakultas Ekonomi dan Bisnis Universitas Udayana. Sumber data sekunder dalam penelitian ini adalah informasi data jumlah mahasiswa jurusan akuntansi regular pagi dan regular siang angkatan 2015, 2016, 2017 dan 2018 Fakultas Ekonomi dan Bisnis. 
Analisis regresi linear berganda dilakukan untuk mengetahui hubungan antara lebih dari dua variabel, yang dalam penelitian ini adalah untuk mengetahui pengaruh persepsi kemudahan penggunaan, persepsi kegunaan dan persepsi risiko terhadap minat menggunakan sistem blockchain. Analisis ini dilakukan dengan menggunakan program Statistical Package for Social Science (SPSS) dengan tingkat signifikansi $5 \%(\alpha=0,05)$. Persamaan analisis regresi linier berganda yaitu:

$Y=\alpha+\beta_{1} X_{1}+\beta_{2} X_{2}+\beta_{3} X_{3}+\Sigma$

Keterangan:

$\mathrm{Y}=$ Minat Menggunakan Sistem Blockchain

$\alpha=$ Konstanta

$\mathrm{X} 1$ = Persepsi Kemudahan

$\mathrm{X} 2$ = Persepsi Kegunaan

X 3 = Persepsi Risiko

$\beta_{1}-\beta_{3}=$ Koefisien regresi variabel independent

$\Sigma=$ Standar error

\section{HASIL DAN PEMBAHASAN}

Responden dari peneltian ini adalah mahasiswa S1 angakatan 2015, 2016, 2017 dan 2018 jurusan akuntansi Fakultas Ekonomi dan Bisnis Universitas Udayana. Kuesioner yang disebarkan kepada responden sebanyak 294 eksemplar dengan tingkat pengembarian responden 100 persen. Tingkat pengembalian yang dapat dianalisis sebesar 100 persen dengan rincian sebagai berikut. 
Tabel 2.

Data Pengiriman dan Pengembalian Kuesioner

\begin{tabular}{lc}
\hline \multicolumn{1}{c}{ Keterangan } & Jumlah \\
\hline Total Kuesioner yang disebar & 294 \\
Kuesioner yang tidak kembali & 0 \\
Kuesioner yang dikembalikan & 294 \\
Kuesioner yang tidak dapat digunakan & 0 \\
Kuesioner yang digunakan dalam analisis & 294 \\
Tingkat Pengembalian/Response Rate & $100 \%$ \\
Tingkat Pengembalian yang digunakan / Usable Rate & $100 \%$ \\
\hline Sumber: Data diolah, 2019 &
\end{tabular}

Pada tabel 2. diatas menunjukan bahwa jumlah kuesioner yang disebarkan kepada responden sebanyak 294 kuesioner dan yang dikembalikan sebanyak 294 kuesioner dan setelah diperiksa semua kuesioner layak untuk digunakan pada analisis selanjutnya.

Tabel 3.

Karakteristik Responden

\begin{tabular}{clcc}
\hline No & \multicolumn{1}{c}{ Keterangan } & Jumlah & Persentase (\%) \\
\hline 1. & Jenis Kelamin: & 86 & $29,3 \%$ \\
& -Laki-laki & 208 & $70,7 \%$ \\
& -Perempuan & 294 & $100 \%$ \\
& Jumlah & & \\
2. & Usia & 136 & $46,3 \%$ \\
& $-16-20$ & 158 & $53,7 \%$ \\
& $-21-24$ & 0 & $0 \%$ \\
& $->25$ & 294 & $100 \%$ \\
& Jumlah & & \\
3ngkatan & -2015 & 134 & $45,6 \%$ \\
& -2016 & 30 & $10,2 \%$ \\
& -2017 & 59 & $20,1 \%$ \\
& -2018 & 71 & $24,1 \%$ \\
& Jumlah & 294 & $100 \%$ \\
\hline
\end{tabular}

Sumber: Data diolah, 2019

Berdasarkan Tabel 3, diatas dapat dijelaskan profil jenis kelamin digunakan untuk mengetahui proporsi responden pria dan wanita. Tabel 3 menunjukkan bahwa responden yang berjenis kelamin laki-laki sebanyak 86 orang $(29,3 \%)$ dan responden yang berjenis kelamin wanita 208 orang (70,7\%).Profil usia pada tabel 3 menunjukkan bahwa responden yang berumur 16-20 tahun sebanyak 136 orang 
(46,3\%), usia 21-24 tahun sebanyak 158 orang (53,7\%), dan usia >25 tahun sebanyak 0 orang (0\%).Profil angkatan pada tabel 4.2 menunjukan bahwa responden angkatan 2015 sebanyak 134 orang (45,6\%), angkatan 2016 sebanyak 30 orang (10,2\%), angkatan 2017 sebanyak 59 orang (20,1\%) dan angkatan 2018 sebanyak 71 orang $(24,1 \%)$.

Tabel 4.

Hasil Uji Statistik Deskriptif

\begin{tabular}{|c|c|c|c|c|}
\hline Variabel & $\begin{array}{c}\text { Nilai } \\
\text { Maksimum }\end{array}$ & $\begin{array}{c}\text { Nilai } \\
\text { Minimum }\end{array}$ & Mean & $\begin{array}{l}\text { Standar } \\
\text { Deviasi }\end{array}$ \\
\hline $\begin{array}{l}\text { Persepsi Kegunaan } \\
\left(\mathrm{X}_{1}\right)\end{array}$ & 4,00 & 2,25 & 16,40 & 1,982 \\
\hline $\begin{array}{l}\text { Persepsi Kemudahan } \\
\text { Penggunaan }\left(\mathrm{X}_{2}\right)\end{array}$ & 4,00 & 2,40 & 16,81 & 2,052 \\
\hline Persepsi Risiko $\left(\mathrm{X}_{3}\right)$ & 4,00 & 1,00 & 9,05 & 2,104 \\
\hline $\begin{array}{l}\text { Minat Menggunakan } \\
\text { (Y) }\end{array}$ & 4,00 & 2,33 & 10,00 & 1,269 \\
\hline
\end{tabular}

Sumber: Data diolah, 2019

Berdasarkan Tabel 4. dapat dijelaskan hasilnya sebagai berikut.Variabel Kegunaan $\left(\mathrm{X}_{1)}\right.$ hasil pengujian statistik deskriptif menunjukan nilai minimum sebesar 2,25, nilai maksimum sebesar 4,00, rata-rata (mean) sebesar 16,40 dan standar deviasi sebesar 1,982 . Hal ini menunjukan terjadinya perbedaan dari hasil jawaban responden mengenai minat mahasiswa akuntansi menggunakan sistem blockchain dalam teknologi keuangan terhadap nilai rata-ratanya sebesar 16,40.

Persepsi Kemudahan Penggunaan $\left(\mathrm{X}_{2}\right)$ memiliki nilai minimum sebesar 2,40, nilai maksimum sebesar 4,00, rata-rata (mean) 16,81 dan standar deviasi sebesar 2,052. Hal ini menunjukan terjadinya perbedaan dari hasil jawaban responden mengenai minat mahasiswa akuntansi menggunakan sistem blockchain dalam teknologi keuangan terhadap nilai rata-ratanya sebesar 16,81.Persepsi Risiko $\left(\mathrm{X}_{3}\right)$ memiliki nilai minimum sebesar 1,00 , nilai maksimum sebesar 4,00, 
rata-rata (mean) 9,05 dan standar deviasi sebesar 2,104. Hal ini menunjukan terjadinya perbedaan dari hasil jawaban responden mengenai minat mahasiswa akuntansi menggunakan minat sistem blockchain dalam teknologi keuangan terdahap nilai rata-ratanya sebesar 9,05.

Minat Menggunakan (Y) memiliki nilai minimum sebesar 2,33, nilai maksimum sebesar 4,00, rata-rata (mean) 10,00 dan nilai standar deviasi sebesar 1,269. Hal ini menunjukan terjadinya perbedaan dari hasil jawaban responden mengenai kemudahan penggunaan, kegunaan, risiko penggunaan dan minat menggunakan terhadap nilai rata-ratanya sebesar 10,00.

Tabel 5.

Hasil Uji Validitas

\begin{tabular}{ccccc}
\hline No. & \multicolumn{1}{c}{ Variabel } & Kode Instrumen & Koefisien Korelasi & Keterangan \\
\hline 1. & Persepsi Kegunaan $\left(\mathrm{X}_{1}\right)$ & $\mathrm{X}_{1} \cdot 1$ & 0,862 & Valid \\
& & $\mathrm{X}_{1} \cdot 2$ & 0,902 & Valid \\
& & $\mathrm{X}_{1} \cdot 3$ & 0,824 & Valid \\
& & $\mathrm{X}_{1} \cdot 4$ & 0,689 & Valid \\
2. & Persepsi Kemudahan & $\mathrm{X}_{1} \cdot 5$ & 0,784 & Valid \\
& Penggunaan $\left(\mathrm{X}_{2}\right)$ & $\mathrm{X}_{2} \cdot 1$ & 0,688 & Valid \\
& & $\mathrm{X}_{2} \cdot 2$ & 0,837 & Valid \\
& & $\mathrm{X}_{2} \cdot 3$ & 0,838 & Valid \\
& & $\mathrm{X}_{2} \cdot 4$ & 0,796 & Valid \\
3. & Persepsi Risiko $\left(\mathrm{X}_{3}\right)$ & $\mathrm{X}_{2} \cdot 5$ & 0,621 & Valid \\
& & $\mathrm{X}_{3} \cdot 1$ & 0,903 & Valid \\
& $\mathrm{X}_{3} \cdot 2$ & 0,673 & Valid \\
& $\mathrm{X}_{3} \cdot 3$ & 0,767 & Valid \\
4. & $\mathrm{X}_{3} \cdot 4$ & 0,766 & Valid \\
& Minat Menggunakan Sistem & $\mathrm{Y}_{1}$ & 0,858 & Valid \\
& Klockchain Dalam Teknologi & $\mathrm{Y}_{2}$ & 0,777 & Valid \\
& Keuangan (Y) & $\mathrm{Y}_{3}$ & 0,892 & Valid \\
\hline
\end{tabular}

Sumber: Data diolah, 2019

Berdasarkan Tabel 5 dapat diketahui bahwa instrument pada tiap variabel dalam penelitian ini telah memenuhi syarat validitas, karena nilai koefisien korelasi setiap instrument lebih besar dari 0,3 
Tabel 6.

Hasil Uji Reabilitas

\begin{tabular}{lcc}
\hline \multicolumn{1}{c}{ Variabel } & Nilai Cronbach's Alpha & Keterangan \\
\hline Persepsi Kegunaan $\left(\mathrm{X}_{1}\right)$ & 0,871 & Reliabel \\
Persepsi Kemudahan Penggunaan $\left(\mathrm{X}_{2}\right)$ & 0,807 & Reliabel \\
Persepsi Risiko $\left(\mathrm{X}_{3}\right)$ & 0,764 & Reliabel \\
Minat Menggunakan Sistem Blockchain Dalam & 0,793 & Reliabel \\
Teknologi Keuangan $(\mathrm{Y})$ & &
\end{tabular}

Sumber: Data diolah, 2019

Berdasarkan Tabel 6 dapat diketahui bahwa semua instrument penelitian dinyatakan reliabel karena setiap variabel memiliki nilai cronbach's alpha< 0,7 yakni lebih besar dari 0,05 .

Tabel 7.

Hasil Uji Normalitas

\begin{tabular}{ccc}
\hline Model & N & Asymp.Sig.(2-tailed) \\
\hline Regresi & 294 & 0,168 \\
\hline Sumber: Data diolah, 2019 &
\end{tabular}

Sumber: Data diolah, 2019

Berdasarkan Tabel 7 diatas dapat dilihat bahwa angka probabilitas atau Asymp. Sig (2-tailed) menunjukkan nilai 0,168 yakni lebih besar dari 0,05 yang artinya bahwa seluruh data dapat dikatakan berdistribusi normal

Tabel 8.

Hasil Uji Multikolineritas

\begin{tabular}{lcc}
\hline \multicolumn{1}{c}{ Variabel } & \multicolumn{2}{c}{ Collinearity Statistic } \\
& Tolerance & VIF \\
\hline Persepsi Kegunaan $\left(\mathrm{X}_{1}\right)$ & 0,648 & 1,542 \\
Persepsi Kemudahan Penggunaan $\left(\mathrm{X}_{2}\right)$ & 0,643 & 1,554 \\
Persepsi Risiko $\left(\mathrm{X}_{3}\right)$ & 0,987 & 1,013 \\
\hline
\end{tabular}

Sumber: Data diolah, 2019

Berdasarkan Tabel 8 dapat dilihat bahwa hasil uji multikolinieritas menunjukkan bahwa masing-masing variabel bebas memiliki nilai tolerance dan nilai VIF dari masing-masing variabel bebas tersebut, maka dapat disimpulkan bahwa tidak ada multikolinieritas antar variabel bebas dalam model regresi. 
Tabel 9.

Hasil Uji Heteroskedastitas

\begin{tabular}{lcc}
\hline \multicolumn{1}{c}{ Variabel } & Sig. & Keterangan \\
\hline Persepsi Kegunaan $\left(\mathrm{X}_{1}\right)$ & 0,577 & Bebas Heteroskedastisitas \\
Persepsi Kemudahan Penggunaan $\left(\mathrm{X}_{2}\right)$ & 0,624 & Bebas Heteroskedastisitas \\
Persepsi Risiko $\left(\mathrm{X}_{3}\right)$ & 0,235 & Bebas Heteroskedastisitas \\
\hline
\end{tabular}

Sumber: Data diolah, 2019

Berdasarkan Tabel 9 diketahui nilai signifikansi masing-masing variabel bebas lebih besar dari 0,05 sehingga dapat disimpulkan bahwa model regresi dalam penelitian ini bisa bebas dari gejala heteroskedastisitas.

Analisis regresi linear berganda dilakukan untuk mengetahui hubungan antar lebih dari dua variabel. Hasil analisis regresi linier berganda disajikan pada Tabel 10 sebagai berikut.

Tabel 10.

Hasil Analisis Linear Berganda

\begin{tabular}{lccccr}
\hline \multicolumn{1}{c}{ Model } & \multicolumn{2}{c}{$\begin{array}{c}\text { Unstandardized } \\
\text { Coefficients }\end{array}$} & $\begin{array}{c}\text { Standardized } \\
\text { Coefficients }\end{array}$ & T & Sig \\
\cline { 2 - 4 } & $\mathrm{B}$ & Std. Error & Beta & & \\
\hline (Constant) & 3,423 & 0,710 & & 4,821 & 0,000 \\
Persepsi Kegunaan $\left(\mathrm{X}_{1}\right)$ & 0,276 & 0,035 & 0,431 & 7,808 & 0,000 \\
Persepsi Kemudahan & 0,182 & 0,034 & 0,293 & 5,290 & 0,000 \\
Penggunaan $\left(\mathrm{X}_{2}\right)$ & & & & & \\
Persepsi Risiko $\left(\mathrm{X}_{3}\right)$ & $-0,080$ & 0,039 & $-0,091$ & $-2,040$ & 0,042 \\
AdjustedR & & & & & 0,420 \\
F & & & & & 71,691 \\
Sig. F & & & & & 0,000 \\
\hline Sumber: & & & & & \\
\hline
\end{tabular}

Sumber: Data diolah, 2019

Berdasarkan tabel 10. diatas diperoleh suatu persamaan regresi sebagai berikut:

$$
\begin{aligned}
& \mathrm{Y}=\alpha+\beta_{1} \mathrm{X}_{1}+\beta_{2} \mathrm{X}_{2}+\beta_{3} \mathrm{X}_{3}+\mathrm{e} \\
& \mathrm{Y}=3,423+0,276 \mathrm{X}_{1}+0,182 \mathrm{X}_{2}-0,080 \mathrm{X}_{3}+\sum
\end{aligned}
$$

Persamaan regresi tersebut dapat diinterprestasikan sebagai berikut.Nilai konstanta $(\alpha)$ sebesar 3,423 memiliki arti jika variabel persepsi kegunaan $\left(\mathrm{X}_{1}\right)$, persepsi kemudahan pengunaan $\left(\mathrm{X}_{2}\right)$, persepsi risiko $\left(\mathrm{X}_{3}\right)$ sama dengan nol, maka 
nilai variabel persepsi kegunaan bernilai positif sebesar 3,423. Nilai $\beta_{1}$ sebesar 0,276 berarti jika variabel persepsi kegunaan meningkat, maka mengakibatkan peningkatan terhadap minat menggunakan sistem blockchain dalam teknologi keuangan dengan asumsi variabel bebas lainnya konstan.

Nilai $\beta_{2}$ sebesar 0,182 berarti jika variabel persepsi kemudahan penggunaan meningkat, maka mengakibatkan peningkatan terhadap minat menggunakan sistem blockchain dalam teknologi keuangan dengan asumsi variabel bebas lainnya konstan.Nilai $\beta_{3}$ sebesar $-0,080$ berarti jika variabel persepsi risiko meningkat, maka mengakibatkan penurunan terhadap minat menggunakan sistem blockchain dalam teknologi keuangan dengan asumsi variabel bebas lainnya konstan.

Berdasarkan Tabel 10. menunjukkan bahwa nilai Adjusted $R$ Square adalah 0,420 atau $42 \%$, ini artinya sebesar $42 \%$ variasi minat menggunakan sistem blockchain dalam teknologi keuangan mahasiswa S1 jurusan akuntansi dipengaruhi oleh persepsi kegunaan, persepsi kemudahan penggunaan dan persepsi risiko. Sedangkan sisanya sebesar $58 \%$ dijelaskan oleh faktor lain yang tidak dimasukkan dalam model penelitian ini.

Hasil penelitian ini dilihat berdasarkan uji hipotesis (uji t) pengaruh persepsi kegunaan, menunjukan hasil koefisien regresi 0,276 dengan signifikansi 0,000 <alpha $=0,05$ yang berarti $\mathrm{H}_{1}$ diterima yaitu pengaruh persepsi kegunaan memberikan pengaruh yang siginifikan pada minat menggunakan. Koefisien regresi bernilai 0,276 menunjukan bahwa pengaruh persepsi kegunaan berpengaruh positif terhadap minat menggunakan sistem blockchain dalam 
teknologi keuangan. Hal ini berarti sejalan dengan teori TAM (Theory Acceptent Model) yang menyatakan persepsi kegunaan merupakan suatu konstruk keyakinan seseorang bahwa penggunaan sebuah teknologi tertentu akan mampu meningkatkan kinerja mereka. Hal ini konsisten dengan hasil penelitian Syaninditha \& Setiawan (2017), Delima (2016) yang menunjukan bahwa persepsi kegunaan berpengaruh positif pada minat menggunakan.

Hasil penelitian berdasarkan uji hipotesis (uji t) pengaruh persepsi kemudahan penggunaan, menunjukan hasil koefisien regresi 0,182 dengan signifikansi $0,000<a l p h a=0,05$ yang berarti $\mathrm{H}_{2}$ diterima yaitu pengaruh persepsi kemudahan penggunaan memberikan pengaruh yang signifikan pada minat menggunakan. Koefisien regresi bernilai 0,128 menunjukan bahwa pengaruh persepsi kemudahan penggunaan berpengaruh positif terhadap minat menggunakan sistem blockchain dalam teknologi keuangan, sehingga hipotesis kedua diterima. Hal ini sejalan dengan teori yang dicetuskan oleh Martin Fishbein dan Ajzen. Dimana dalam teori ini keyakinan (belief), sikap (attitude), kehendak (intention), dan perilaku (behavior). Kehendak merupakan prediktor terbaik dalam perilaku, artinya jika ingin mengetahui apa yang akan dilakukan seseorang, cara terbaik adalah mengetahui kehendak orang tersebut. Namun, seseorang dapat membuat pertimbangan berdasarkan alasan-alasan yang sama sekali berbeda (tidak selalu berdasarkan kehendak). Hasil penelitian ini konsisten dengan penelitian Dewi (2017) yang menyatakan bahwa persepsi kebermanfaatan berpengaruh terhadap minat menggunakan E-Banking. 
Hasil penelitian berdasarkan uji hipotesis (uji t) variabel persepsi risiko menunjukan hasil koefisien regresi $-0,080$ dengan signifikansi $0,042<$ alpha $=$ 0,05 yang berarti $\mathrm{H}_{3}$ diterima yaitu persepsi risiko dapat memberikan pengaruh yang signifikan pada minat menggunakan. Hasil koefisien regresi $-0,080$ yang menunjukan bahwa persepsi risiko berpengaruh negatif pada minat menggunakan sistem blockchain dalam teknologi keuangan. Hal ini sejalan dengan teori yang dicetuskan oleh Martin Fishbein dan Ajzen. Dimana dalam teori ini keyakinan (belief), sikap (attitude), kehendak (intention), dan perilaku (behavior). Hasil penelitian ini konsisten dengan Sebayang (2017) dan Dwimastia Harlan (2014) dimana hasil penelitiannya menunjukan bahwa persepsi risiko berpengaruh negatif terhadap minat menggunakan E-Banking.

\section{SIMPULAN}

Berdasarkan hasil penelitian mengenai pengaruh persepsi kegunaan, persepsi kemudahan penggunaan dan persepsi risiko terhadap minat menggunakan sistem blockchain dalam teknologi keuangan dapat disimpulkan bahwa:Persepsi kegunaan berpengaruh positif pada minat menggunakan sistem blockchain. Hal ini menunjukan bahwa semakin tinggi persepsi kegunaan maka semakin tinggi pula minat pengguna untuk menggunakan sistem blockchain dalam teknologi keuangan.

Persepsi kemudahan penggunaan berpengaruh positif terhadap minat menggunakan sistem blockchain. Hal ini menunjukan bahwa semakin tinggi persepsi kemudahan maka semakin tinggi pula minat pengguna untuk 
menggunakan sistem blockchain dalam teknologi keuangan.Persepsi risiko berpengaruh negatif terhadap minat menggunakan sistem blockchain. Hal ini menunjukan bahwa semakin tinggi persepsi risiko maka minat menggunakan sistem blockchain dalam teknologi keuangan semakin rendah.

Berdasarkan kesimpulan diatas, selanjutnya dapat diusulkan saran yang diharapkan dapat bermanfaat bagi pengguna uang elektronik, dapat bermanfaat bagi mahasiswa-mahasiswi akuntansi. Bagi penelitian selanjutnya disarankan untuk mengkategorikan responden lebih luas, tidak hanya mencangkup mahasiswa-mahasiswi S1 jurusan akuntansi saja namun bisa mengkategorikan responden lebih luas lagi seperti seluruh mahasiswa-mahasiswi Fakultas Ekonomi dan Bisnis.

\section{REFERENSI}

andrie, S. (2012). Kemudahan, Dan Persepsi Risiko Terhadap Perilaku Penggunaan E-Commerce Disusun Oleh: Andrie Cesario Shomad Dosen Pembimbing : Jurnal Ilmiah Mahasiswa Feb Universitas Brawijaya, 1(2), 120.

Aritonang, Y. A. L., \& Arisman, A. (2017). Pengaruh Persepsi Kemudahan Dan Persepsi Manfaat Terhadap Minat Menggunakan E-Money. Jurnal Akuntansi Stie Multi Data Palembang.

Az Zahra, F. (2018). Pengaruh Perceived Usefulness, Perceived Ease Of Use Dan Perceived Risk Terhadap Intention To Shop Online. Jurnal Ilmiah Mahasiswa Feb Universitas Brawijaya. $\backslash$

Azjen, I. (1991). The Theory Of Planned Behavior. Organizational Behavior And Human Decision Processes. Https://Doi.Org/10.1922/Cdh_2120vandenbroucke08

Bank Indonesia. (2016). Bank Indonesia. Peraturan Bank Indonesia Nomor 18/40/Pbi/2016 Tentang Pemrosesan Transaksi, Pub. L. No. 18/40/Pbi/2016 (2016). 
Beritautama.Net. (2018). Jokowi: Anak Muda Harus Siap Dengan Revolusi Industri 4.0, (Diakses: Https://Beritautama.Net/News/Jokowi-Anak-MudaHarus-Siap-Dengan-Revolusi-Industri-4-0/).

Cahyo, W. Y. H. (2014). Pengaruh Persepsi Kebermanfaatan, Keamanan, Kepercayaan Dan Persepsi Kemudahan Penggunaan Terhadap Penggunaan Online Banking Pada Mahasiswa S1 Fakultas Ekonomi Universitas Negeri Yogyakarta. Skripsi Universitas Negeri Yogyakarta.

Cho, J. \& Lee, J. (2006). An Integrated Model Of Risk And Risk-Reducing Strategies. Journal of Business Research, 59(1), Doi: 10.1016/ J.Jbusres.2005.03.006.

Davis, F. D. (1989). Perceived Usefulness, Perceived Ease Of Use, And User Acceptance Of Information Technology. Mis Quarterly. Https://Doi.Org/10.2307/249008

Delima, N. E. \& Z. M. (2016). Pengaruh Persepsi Kemudahan Penggunaan, Persepsi Kegunaan, Dan Pengalaman Terhadap Minat Wajib Pajak Menggunakan Sistem E-Filing (Studi Kasus Wajib Pajak Orang Pribadi Di Kabupaten Pati). Jurnal Akuntansi Indonesia, 5(2).

Departemen Komunikasi Bank Indonesia. (2014). Bank Indonesia Mencanangkan Gerakan Nasional Non Tunai (Gnnt), (Retrieved From Https://Www.Bi.Go.Id/Id/Ruang-Media/SiaranPers/Pages/Sp_165814.Aspx).

Dewantara, A. L. Dan. (2015). Pengaruh Persepsi Kemanfaatan, Persepsi Kemudahan Penggunaan, Persepsi Resiko Dan Persepsi Kesesuaian Terhadap Minat Menggunakan Mobile Banking (Studi Pada Nasabah Bank Rakyat Indonesia (Bri) Kantor Cabang Rembang, Jawa Tengah). Jurnal Administrasi Bisnis (Jab), 26(2).

Dewi, N. L. P. E. P. (2017). Pengaruh Persepsi Kebermanfaatan, Kemudahan Penggunaan, Dan Keamanan Terhadap Minat Menggunakan Ebanking Pada Mahasiswa Jurusan Akuntansi Program S1 Fakultas Ekonomi Universitas Pendidikan Ganesha. Skripsi Universitas Pendidikan Ganesha. Skripsi Universitas Pendidikan Ganesha.

Dwimastia Harlan. (2014). Pengaruh Kemudahan Penggunaan, Kepercayaan Dan Risiko Persepsian Terhadap Minat Bertransaksi Menggunakan Ebanking Pada Umkm Di Kota Yogyakarta. Skripsi Universitas Negeri Yogyakarta.

Farizi, H., \& Syaefullah. (2013). Pengaruh Persepsi Kegunaan, Persepsi Kemudahan, Persepsi Risiko Dan Kepercayaan Terhadap Minat 
Menggunakan Internet Banking. Jurnal Ilmiah Mahasiswa Feb, 2(1), 1-18. Https://Doi.Org/10.1017/Cbo9781107415324.004

Featherman, Ms. Pavlou, P. (2002). Predicting E-Service Adoption : A Perceived Risk Facets Perspective. Eighth Americas Conference On Information Systems.

Fishbein, M., \& Ajzen, I. (1975). Chapter 2. Theories Of Attitude. Belief, Attitude, Intention, And Behavior, An Introduction To Theory And Research. Https://Doi.Org/10.2307/2065853

Genady, D. I. (2018). Pengaruh Kemudahan, Kemanfaatan, Dan Promosi Uang Elektronik Terhadap Keputusan Penggunaan Uang Elektronik Di Masyarakat (Studi Kasus Di Provinsi Dki Jakarta). Skripsi.

Hair, W. \&. (2010). Essentials Of Marketing Research, (Mcgraw-Hill/Irwin. Inc: New York.).

Hapsari, K. (2015). Kampanye Bank Sentral Di Area Kampus (Studi Kasus Tentang Strategi Kampanye Bank Indonesia Dalam Membentuk Kawasan Less Cash Society Melalui Gerakan Nasional Non Tunai Di Universitas Gajah Mada. Electronic Theses \& Dissertation (Etd) Gadjah Mada University. Https://Doi.Org/10.1192/Bjp.205.1.76a

Hasanah, S. P. \& U. (2018). Integrasi Teknologi Digital Dalam Pembelajaran Di Era Industri 4.0 Kajian Dari Perspektif Pembelajaran Matematika. Jurnal Pemikiran Dan Penelitian Pendidikan, 16(1).

Irmadhani, \& Nugroho, M. A. (2012). Pengaruh Persepsi Kebermanfaatan, Persepsi Kemudahan Penggunaan Dan Computer Self Efficacy, Terhadap Penggunaan Online Banking Pada Mahasiswa S1 Fakultas Ekonomi Universitas Negeri Yogyakarta. Jurnal Kajian Pendidikan Dan Akuntansi Indonesia.

Jayawarna, D., Rouse, J., \& Kitching, J. (2013). Entrepreneur Motivations And Life Course. International Small Business Journal. Https://Doi.Org/10.1177/0266242611401444

Jogiyanto. (2007). Sistem Teknologi Informasi Edisi Iii, (Yogyakarta: Andi).

Kusumastuti, R., \& Waluyo, I. (2019). Pengaruh Motivasi Dan Pengetahuan Uu No.5 Tahun 2011 Tentang Akuntan Publik Terhadap Minat Mahasiswa Akuntansi Mengikuti Pendidikan Profesi Akuntansi (Ppak). Nominal, Barometer Riset Akuntansi Dan Manajemen. Https://Doi.Org/10.21831/Nominal.V2i2.1662 
Lai, P. (2017). The Literature Review Of Technology Adoption Models And Theories For The Novelty Technology. Journal Of Information Systems And Technology Management. Https://Doi.Org/10.4301/S180717752017000100002

Langelo, A. S. E. (2013). Perceived Usefulness, Perceived Ease Of Use, Perceived Risk Impact To Lecturers' Internet Banking Adoption. International Business Administration (Iba), 1(4), 1570-1580.

Leeraphong Dan Mardjo. (2013). Trust And Risk In Purchase Intenation Throught Online Social Network. Journal Of Economic Business And Management, $1(4)$.

Lestari, W. (2013). Persepsi Risiko Dan Kecenderungan Risiko Investor Individu. Jurnal Keuangan Dan Perbankan, 17(1).

Ozturk, A. B. (2016). Customer Acceptance Of Cashless Payment Systems In The Hospitality Industry. International Journal Of Contemporary Hospitality Management. Https://Doi.Org/10.1108/Ijchm-02-2015-0073

Pablo, A. L., \& Sitkin, S. B. (1992). Reconceptualizing The Determinants Of Risk Behavior. The Academy Of Management Review. Https://Doi.Org/10.5465/Amr.1992.4279564

Prasada Bangkara, R., \& Mimba, N. Putu Harta. (2016). Pada Minat Penggunaan Internet Banking Dengan Attitude Toward Using Sebagai Variabel Intervening. E-Jurnal Akuntansi Universitas Udayana.

Pratiwi, D. M. \& R. (2015). Pengaruh Persepsi Manfaat, Persepsi Kemudahan, Persepsi Risiko Dan Fitur Layanan Terhadap Minat Penggunaan Emoney (Studi Kasus Pada Pengguna E-Money Kota Palembang). Jurnal Jurusan Akuntansi Stie Multi Data Palembang.

Ramatsyah, D. (2011). Analisis Faktor-Faktor Yang Mempengaruhi Minat Penggunaan Produk Baru. Thesis Universitas Indonesia, (Depok).

Sari, R. (2013). Pengaruh Persepsi Kebermanfaatan, Kepercayaan, Dan Computer Self Efficacy Terhadap Penggunaan E-Banking Pada Mahasiswa S1 Fakultas Ekonomi Universitas Negeri Yogyakarta. Skripsi Universitas Negeri Yogyakarta.

Satoshi, N., \&Nakamoto, S. (2008). Bitcoin: A Peer-To-Peer Electronic Cash System. Bitcoin. Https://Doi.Org/10.1007/S10838-008-9062-0

Sayuti. (2012). Kajian Efektivitas Penerimaan Dan Penggunaan Metode Pembelajaran Berbasis Blended E-Learning (Studi Kasus Pada Fakultas Ilmu 
Komputer UPN "Veteran” Jakarta. Budi Luhur University.

Schwab, K. (2016). The Fourth Industrial Revolution: What It Means, How To Respond.

Sebayang. (2017). Pengaruh Risiko, Kemudahan Penggunaan, Kepercayaan, Dan Electronic Word Of Mouth Terhadap Penggunaan Layanan Mobile Banking. Skripsi Universitas Lampung.

Surendran, P. (2012). Technology Acceptance Model: A Survey Of Literature. International Journal Of Business And Social Research, 2(4), 175-178. Https://Doi.Org/Http://Dx.Doi.Org/10.1853.

Syaninditha, S. A. P., \&Putu Ery Setiawan. (2017). Pengaruh Persepsi Kegunaan, Persepsi Kemudahan, Faktor Sosial, Dan Kondisi Yang Memfasilitasi Terhadap Minat Penggunaan E-Filling. E-Jurnal Akuntansi Universitas Udayana.

Taylor, S., \&Todd, P. A. (1995). Understanding Information Technology Usage: A Test Of Competing Models. Information Systems Research. Https://Doi.Org/10.1287/Isre.6.2.144

Utama, M. S. (2014). Aplikasi Analisis Kuantitatif. Denpasar, Fakultas Ekonomi Dan Bisnis Universitas Udayana.

Wardhana, O. H. P. (2016). Pengaruh Persepsi Kemudahan, Persepsi Kegunaan, Persepsi Nilai, Pengaruh Sosial, Persepsi Risiko, Dan Kepercayaan Terhadap Minat Menggunakan E-Commerce. Junal Ilmiah Mahasiswa FEB Universitas Udayana, 4(2).

Wibowo, A. (2008). Kajian Tentang Perilaku Pengguna Sistem Informasi Dengan Pendekatan Technology Acceptance Model ( TAM ). Jurnal Sistem Informasi Universitas Sanata Dharma Yogyakarta. 